\title{
CORRECTION
}

\section{Correction to: The cost of cancer care: how far would you go for a trial?}

Orla M. Fitzpatrick ${ }^{1} \cdot$ Catherine Murphy $^{1} \cdot$ Erica Duignan $^{1} \cdot$ Keith Egan $^{1} \cdot$ Bryan T. Hennessy $^{1} \cdot$ Liam Grogan $^{1}$. Adrian Murphy ${ }^{1}$. Oscar S. Breathnach ${ }^{1}$. Jarushka Naidoo ${ }^{1}$. Patrick G. Morris ${ }^{1}$

Published online: 12 February 2022

(C) The Author(s), under exclusive licence to Royal Academy of Medicine in Ireland 2022

\section{Correction to: Irish Journal of Medical Science (2022)} https://doi.org/10.1007/s11845-021-02915-6

Originally, one of the author has a spelling error. The author Jaruska Naidoo should read Jarushka Naidoo.

The original article has been corrected.

Publisher's Note Springer Nature remains neutral with regard to jurisdictional claims in published maps and institutional affiliations.

The original article can be found online at https://doi.org/10.1007/ s11845-021-02915-6.

Orla M. Fitzpatrick

orlafitzpatrick@rcsi.com

1 Cancer Clinical Trials and Research Unit, Medical Oncology Department, Beaumont RCSI Cancer Centre, Beaumont Hospital, Dublin, Ireland 